zeszyt $163,2020,51-66$

doi: 10.4467/20833113PG.20.016.13212

Instytut Geografii i Gospodarki Przestrzennej UJ

Komisja Geograficzna, Polska Akademia Umiejętności

Wydawnictwo Uniwersytetu Jagiellońskiego

\title{
„SZTUKA PARKOWANIA” - WYKORZYSTANIE PARKINGÓW KAMPUSU 600-LECIA ODNOWIENIA UNIWERSYTETU JAGIELLOŃSKIEGO W KONTEKŚCIE POLITYKI ZRÓWNOWAŻONEJ MOBILNOŚCI
}

\author{
Græegor: Bubak, Andræej Jabtonski, Jakub Biesaga
}

\section{"The art of parking" - using the car parks of the Campus of the 600th Anniversary of the Jagiellonian University Revival in the context of sustainable mobility policy}

Abstract: Sustainable mobility is one of the most current challenges of contemporary spatial planning, which focuses also on parking policy. Keeping balance between the demand and supply of parking space as well as using those in public space is under debate in many cities. The goal of the research was to evaluate the efficiency of parking policy on the 3rd Jagiellonian University Campus in Krakow. For five days, at three fixed times, the occupancy level of parking spaces was measured, and the obtained results were analyzed, which helped Authors to propose a number of spatial and organizational solutions. For a better understanding of the source of the problems, photographical documentation was made and unstructured interviewing was conducted. The Authors came to a conclusion that the parking space resources are used ineffectively despite the fact that the number of parking spots exceeds the demand of users. The obtained results were discussed in relation to the experiences of other universities in the country and in the world. The main idea of the article is to look at the university as an institution with special social responsibility in the implementation of solutions ensuring sustainable mobility.

Keywords: university, campus, sustainable mobility, car parks, transport policy, Jagiellonian University 
Zarys treści: Zrównoważona mobilność jest aktualnym wyzwaniem współczesnego gospodarowania przestrzenią, którego jednym z elementów jest polityka parkingowa. W wielu miastach prowadzone są debaty na temat zachowania równowagi między popytem na miejsca postojowe a ich podażą oraz udziałem tych miejsc w przestrzeni publicznej. Celem badania była ocena efektywności polityki parkingowej na obszarze III Kampusu Uniwersytetu Jagiellońskiego w Krakowie. Przez pięć dni, o trzech stałych porach, dokonano pomiaru zapełnienia miejsc parkingowych, a otrzymane wyniki poddano analizie, co umożliwiło zaproponowanie szeregu rozwiązań przestrzennych i organizacyjnych. Ponadto, przeprowadzono w terenie dokumentację fotograficzną i kilka nieustrukturyzowanych wywiadów, dzięki czemu możliwe było lepsze zrozumienie przyczyn problemów. Najważniejszym wnioskiem badań jest nieefektywne wykorzystanie zaplecza parkingowego, pomimo posiadania zasobów znacznie przekraczających zapotrzebowanie użytkowników. Otrzymane rezultaty omawiane są w odniesieniu do doświadczeń innych szkół wyższych w kraju i na świecie. Myślą przewodnią artykułu jest spojrzenie na uczelnię jako instytucję o szczególnej odpowiedzialności społecznej w zakresie wprowadzania rozwiązań zapewniających zrównoważoną mobilność.

Stowa kluczowe: uczelnia, kampus, zrównoważona mobilność, parkingi, polityka transportowa, Uniwersytet Jagielloński

\section{Wstęp}

W ciągu ostatnich lat podejmowanych jest wiele dyskusji na temat zrównoważonego rozwoju, a wśród nich poruszana jest także kwestia zrównoważonej mobilności (Rudnicki 2010). Dostrzeżono bowiem, jak ważną dziedziną życia człowieka jest przemieszczanie się między różnymi miejscami jego aktywności oraz jak istotny wpływ na środowisko mają usługi związane z przepływem osób i towarów (Rodrigue i in. 2006). Każdą nową inwestycję możemy zatem traktować jako potencjalny generator ruchu, o różnej skali oddziaływania (Bagnowska, Kaczor 2009). Istotą zarządzania zrównoważoną mobilnością stają się zatem plany mobilności, których ważnym punktem jest polityka parkingowa kreowana przez różne podmioty prywatne i publiczne, w tym również jednostki szkolnictwa wyższego (Kowalski, Górecka 2014). Dodatkowo należy zauważyć, że w miastach toczona jest dzisiaj debata na temat zagospodarowywania przestrzeni pod parkingi, a przede wszystkim jaki jest optymalny ich udział w przestrzeni ogółem i jak nimi skutecznie zarządzać (Majdecka i in. 2012; Starowicz 2011). Dyskusja ta dotyczy również kampusów uniwersyteckich (Shoup 2005).

Pojęcie zrównoważonej mobilności (sustainable mobility) oznacza zagospodarowanie przestrzeni i organizację transportu w taki sposób, ażeby zachowania komunikacyjne użytkowników polegały na minimalizacji długości podróży, natomiast mobilność indywidualna nie zagrażała rozwojowi transportu zbiorowego i niezmotoryzowanego. Ponadto, funkcjonowanie tego systemu powinno w jak najmniejszym stopniu wpływać na środowisko naturalne oraz jakość przestrzeni publicznej. 
Dobrą praktyką w zakresie zarządzania mobilnością danej społeczności (np. miasta, przedsiębiorstwa, uczelni) jest wypracowanie planu mobilności, który będzie precyzyjnie definiował priorytety, wyznaczał cele i metody ich osiągnięcia. Nosal (2009) wskazuje, że istotne może być również powołanie odrębnej komórki wewnątrz danej organizacji, koordynującej realizację planu.

Autorzy, obserwując przestrzeń i zachowania kierowców wjeżdżających na obszar Kampusu 600-lecia Odnowienia Uniwersytetu Jagiellońskiego w Krakowie (nazywanego również III kampusem UJ), zwrócili uwagę na dominację przestrzeni uczelnianej przez kierowców samochodów, a rozmieszczenie pojazdów niejednokrotnie utrudniało przemieszczanie się pozostałym użytkownikom. Poczucie, że Uniwersytet jest organizacją o szczególnej odpowiedzialności społecznej, było przyczynkiem do niniejszego opracowania.

\section{Cel pracy i metody badaweze}

Celem badania była ocena ilościowa i jakościowa wykorzystania miejsc parkingowych zlokalizowanych na obszarze Kampusu 600-lecia Odnowienia Uniwersytetu Jagiellońskiego w Krakowie ze szczególnym uwzględnieniem rozkładu przestrzennego i czasowego liczby zaparkowanych pojazdów oraz weryfikacja zapotrzebowania na parkowanie w wyznaczonym obszarze. Należy w tym miejscu zaznaczyć, że badanie miało charakter jednorazowy i eksploracyjny. Opisane w dalszej części wnioski mogą sugerować konieczność jego powtórzenia.

W pierwszym etapie prac dokonano podziału obszaru badań na strefy i podstrefy (Feltynowski 2016) związane z rozmieszczeniem parkingów względem budynków Uniwersytetu, przy jednoczesnym podziale na parkingi o swobodnym i ograniczonym dostępie. Przedmiot badań stanowiły również ulice przecinające obszar kampusu: prof. Łojasiewicza, prof. Demetrykiewicza oraz Gronostajowa (ryc. 1). Z przyczyn technicznych (wysoka czasochłonność badań) z przedmiotu analizy wyłączono sąsiadujący z kampusem parking sklepu wielkopowierzchniowego Kaufland. Z krótkich wywiadów przeprowadzonych w terenie wynika, że również on jest wykorzystywany przez pracowników i studentów Uniwersytetu, ale w sposób bardzo nieregularny. $Z$ analizy wyłączono również prywatny parking strzeżony przy ul. Gronostajowej, bowiem podczas trwania pomiarów korzystali z niego wyłącznie pracownicy pobliskich biurowców, a wjazd był możliwy tylko za stosownym zezwoleniem potwierdzającym wykupienie abonamentu.

Kolejnym etapem badań była inwentaryzacja miejsc parkingowych wyznaczonych i niewyznaczonych. W przypadku miejsc niewyznaczonych liczbę możliwych do zaparkowania pojazdów oszacowano, korzystając z założenia, że jedno miejsce postojowe to prostokąt o wymiarach $5 \mathrm{~m}$ długości i $3 \mathrm{~m}$ szerokości. Szacunki zastosowano dla 


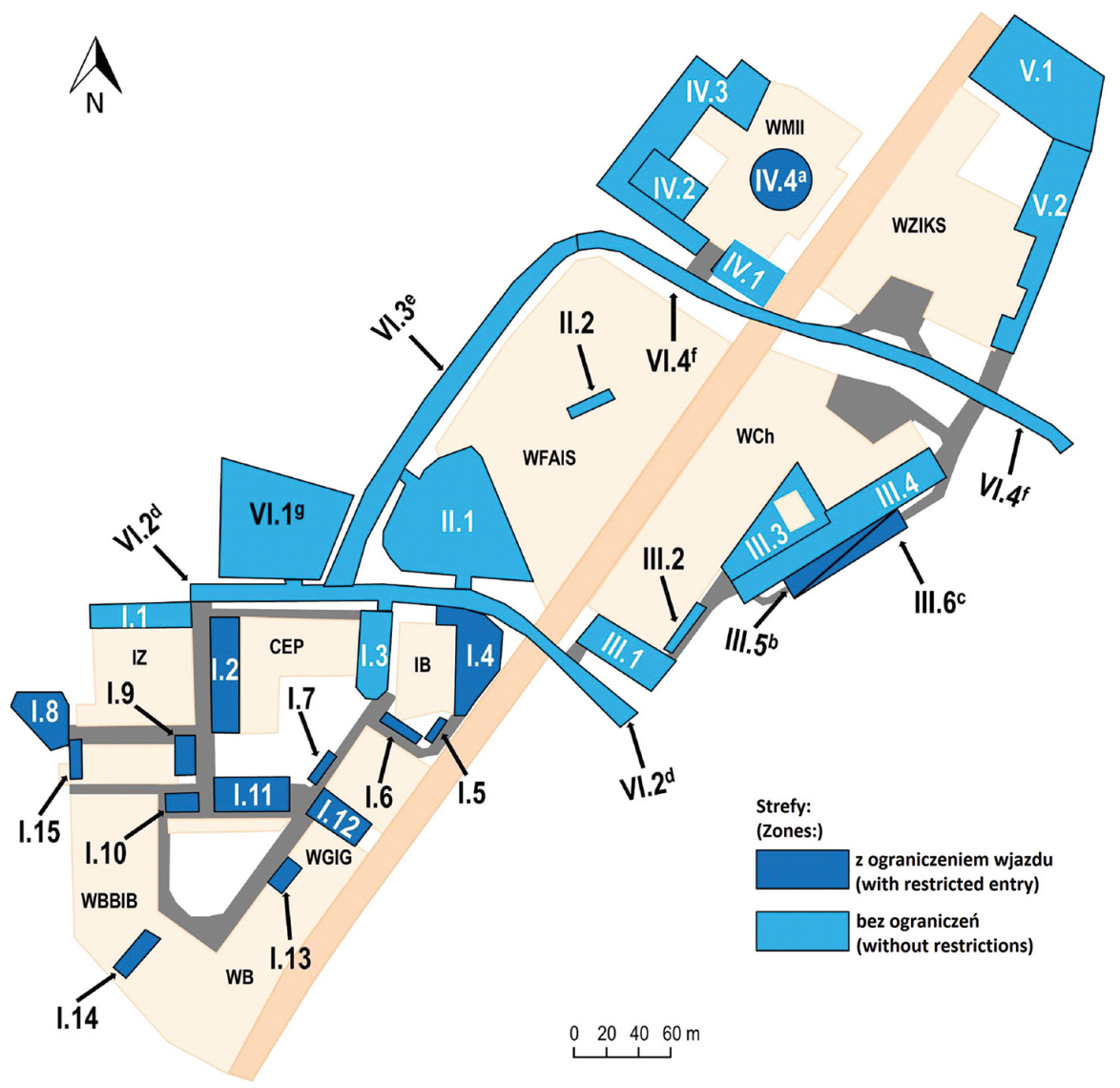

Ryc. 1. Podział parkingów na strefy i podstrefy

Fig. 1. Division of car parks into zones and subzones

Objaśnienia: a - parking podziemny, b - dolna płyta, c - górna płyta, d - ul. Gronostajowa, e - ul. Demetrykiewicza, f - ulica Łojasiewicza, g - szutrowy parking.

Explanations: a - underground car park, b - upper level, c - lower level, d - Gronostajowa Street, e - Demetrykiewicza Street, f - Łojasiewicza Street, g - gravel car park.

parkingu szutrowego oraz ulic przecinających kampus. Dokładne pomiary wykonano przy pomocy oprogramowania GIS stosowanego powszechnie w podobnych badaniach (Templin i in. 2014). W szacowaniu miejsc postojowych na drogach publicznych zastosowanie miały również powszechnie obowiązujące przepisy prawa (ustawa Prawo o ruchu drogowym z dnia 20 czerwca 1997 r. «pón. zm.), zgodnie z którymi przy 
ul. prof. Łojasiewicza postój jest zabroniony na całej długości, przy ul. prof. Demetrykiewicza zabroniony jest po jednej stronie, a przy ul. Gronostajowej dozwolony jest na całej długości ulicy (z uwzględnieniem zasad ogólnych).

Następnym etapem było liczenie wszystkich zaparkowanych pojazdów na obszarze badań. Odbywało się ono każdego dnia od 4 marca 2019 r. do 8 marca 2019 r. o trzech godzinach: 9.00, 13.00 i 17.00, przy czym należy zaznaczyć, że badacze rozpoczynali liczenie w terenie maksymalnie 10 minut przed wyznaczoną godziną, a kończyli maksymalnie 10 minut po wyznaczonej godzinie. Zastosowana metoda badawcza została zaczerpnięta z podobnych badań wykonywanych na obszarze Politechniki Rzeszowskiej (Jedynak 2015), która jako przestrzeń akademicka, stanowiła dobry wzór dla poniższej analizy. Dodatkowo prowadzono niesystematyczne wywiady, obserwacje zachowań oraz dokumentację fotograficzną.

Zdaniem autorów, wpływ na wyniki badań mogły mieć warunki pogodowe: temperatura powietrza we wskazanych dniach wahała się w granicach od $6^{\circ} \mathrm{C}$ do $14^{\circ} \mathrm{C}$, wiatr wiał ze średnią prędkością $20 \mathrm{~km} / \mathrm{h}$ oraz pojawiały się przelotne opady atmosferyczne. W ocenie autorów były to warunki niekorzystne dla amatorów jazdy rowerem lub korzystających z urządzeń transportu osobistego, co mogło dodatkowo zwiększyć liczbę użytkowników samochodów.

\section{Wyniki badań}

\section{Zauważone trendy}

Inwentaryzacja wykazała, że na obszarze badań znajdują się 1423 miejsca postojowe (zał. 1). Dla każdej strefy, oprócz wymienionych podstref, policzono również pojazdy znajdujące się poza parkingami (,inne”). Były to samochody pozostawione na drogach pożarowych, chodnikach czy trawnikach, które nie przylegają bezpośrednio do żadnej z podstref. W przypadku nieprawidłowo zaparkowanych pojazdów na obszarach bezpośrednio przylegających do danej podstrefy zostały one wliczone w jej zapełnienie.

Największe zapełnienie obserwowano każdego dnia o godzinie 13.00, mniejsze o godzinie 9.00, a najmniejsze o 17.00. W skali całego tygodnia najwięcej pojazdów zaparkowanych było w środę, a najmniej w piątek. Ogólnym wynikiem badania był fakt, że pojemność parkingów na obszarze kampusu była wystarczająca względem zapotrzebowania. W szczytowym momencie odnotowano 1001 pojazdów, co stanowi ok. $70 \%$ pojemności maksymalnej. Brak jednak związku między zapełnieniem parkingów a stopniem swobody dostępu do podstrefy (ryc. 1, ryc. 2).

Największą popularnością cieszyły się parkingi zlokalizowane najbliżej wejść do budynków. Ponadto, występowały zarówno strefy o zapełnieniu poniżej 50\%, jak 


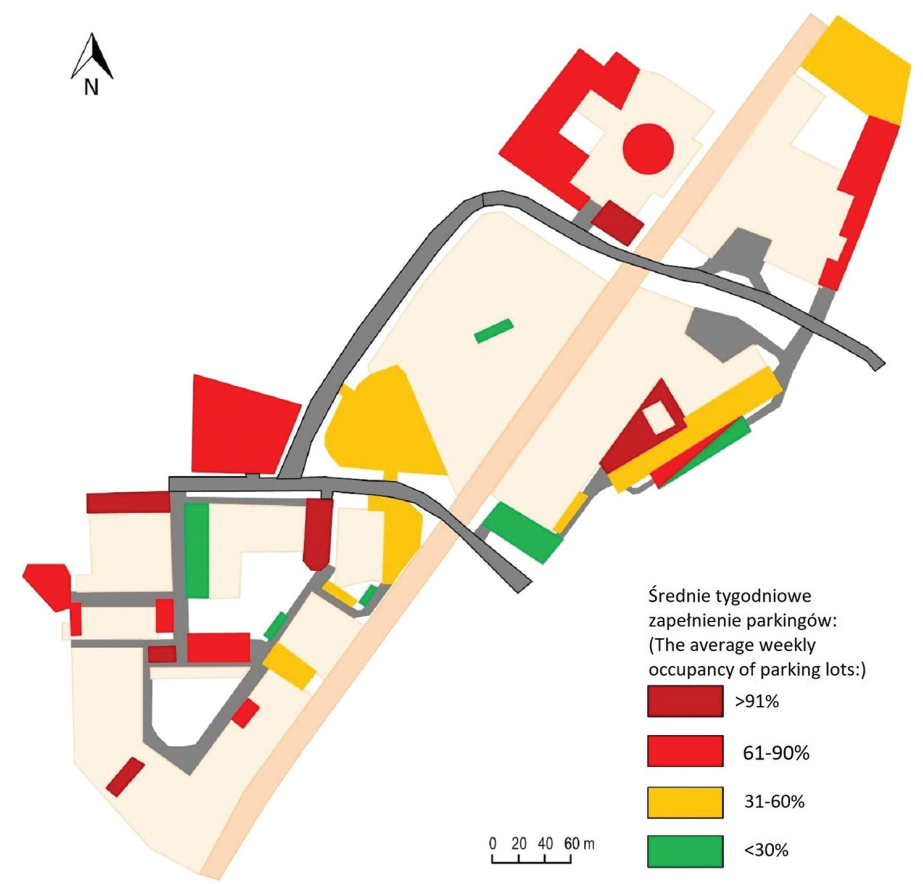

Ryc. 2. Srednie tygodniowe zapełnienie parkingów o godzinie 13.00

Fig. 2. Average weekly occupancy of parking lots at $1 \mathrm{PM}$

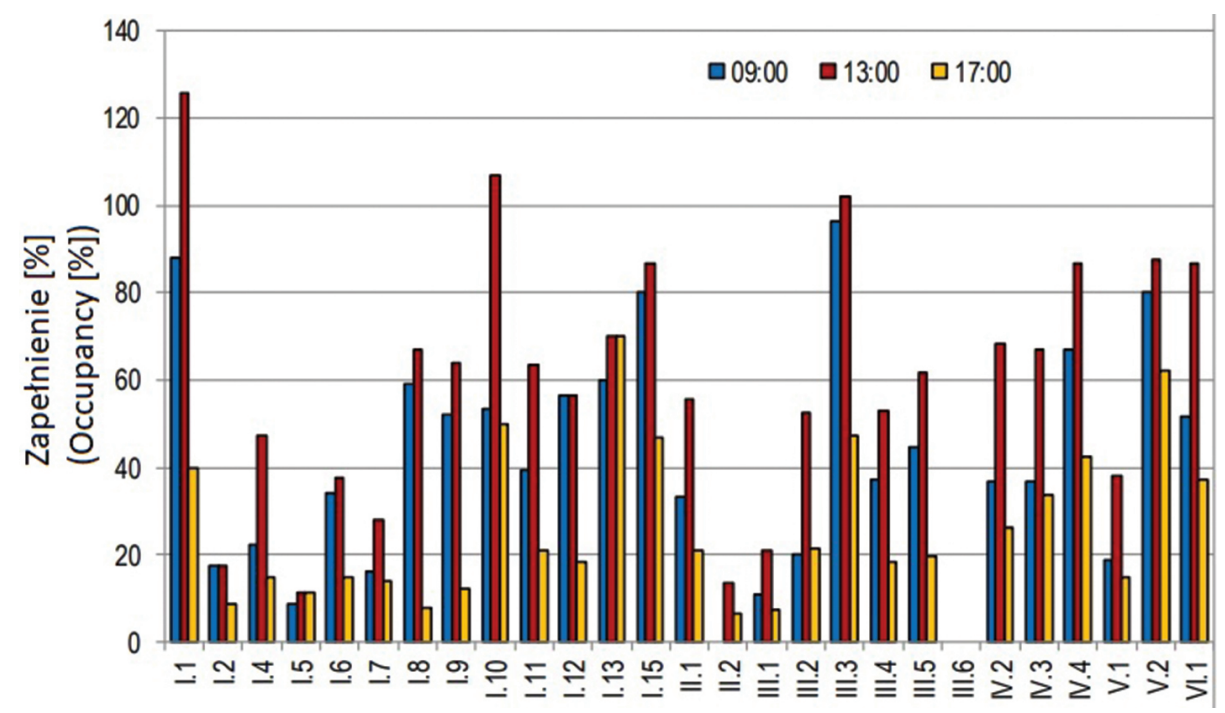

Ryc. 3. Średnie zapełnienie wybranych podstref

Fig. 3. Average occupancy of selected subzones 


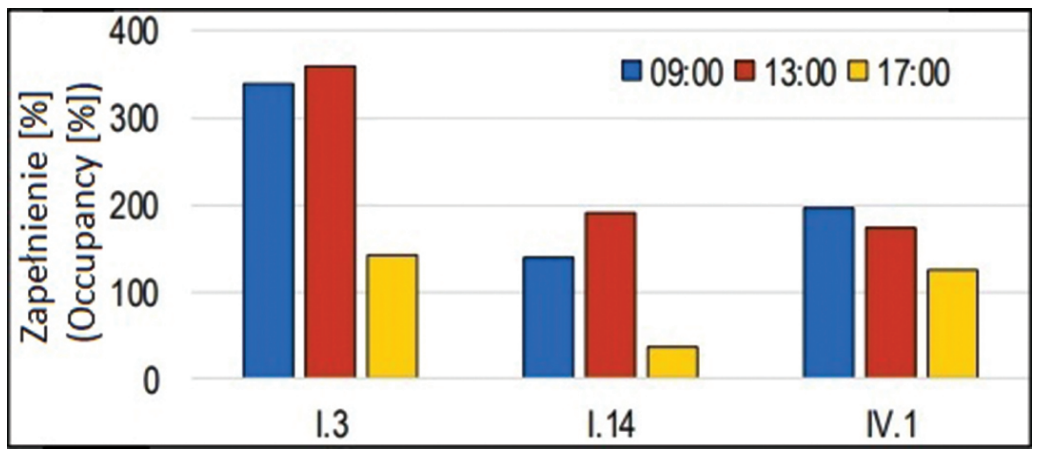

Ryc. 4. Średnie zapełnienie podstref o największym przepełnieniu Fig. 4. Average occupancy of the most overcrowded subzones

i powyżej 100\%, co wiązało się z postojem pojazdów poza miejscami wyznaczonymi (ryc. 3). Część stref charakteryzowała się wysokim przepełnieniem (ryc. 4).

\section{Strefa I - kompleks nauk przyrodniczych}

Strefa I charakteryzowała się największym rozczłonkowaniem parkingów względem reszty kampusu. Istotny również był fakt, że niemal w całości była ona objęta systemem kontroli wjazdu (ryc. 1), co jednak w żaden sposób nie wpłynęło na poprawność zachowań kierowców, czyli respektowanie przez nich przepisów prawa i organizacji ruchu. Autorzy wyróżnili w strefie aż 15 parkingów, z których najmniejszy miał zaledwie 2 miejsca postojowe (I.13), natomiast największy 62 miejsca (I.11).

Na terenie strefy znajdowało się kilka parkingów niecieszących się zainteresowaniem użytkowników (I.2, I.7, I.5), gdzie średnie zapełnienie wynosiło poniżej 30\%, oraz kilka parkingów zapełnionych powyżej 100\% (I.1, I.10, I.14), a nawet wybitnie przepełnionych (I.3). Wynikało to ze wspomnianej bliskości wejść do budynków. W przypadku parkingu I.3 przepełnienie rzędu nawet $350 \%$ wynikało z zajmowania przez kierowców samochodów osobowych miejsc postojowych przeznaczonych dla autobusów oraz dróg dojazdowych. Strefa I odznaczała się również najwyższą liczbą samochodów wymienionych w rubryce „inne” (zał. 1). Była to konsekwencja nagminnego pozostawiania pojazdów na chodnikach oraz drogach pożarowych, szczególnie nieopodal wejścia do Zespołu Dydaktyczno-Bibliotecznego (fot. 1).

Kolejnym istotnym punktem była również kwestia reglamentacji miejsc parkingowych. Większość podstref posiadała ponumerowane miejsca będące w dyspozycji właściwych administratorów jednostek, którzy udostępniali je pracownikom po opłaceniu abonamentu. $Z$ wywiadów przeprowadzonych w terenie wynika, że był 


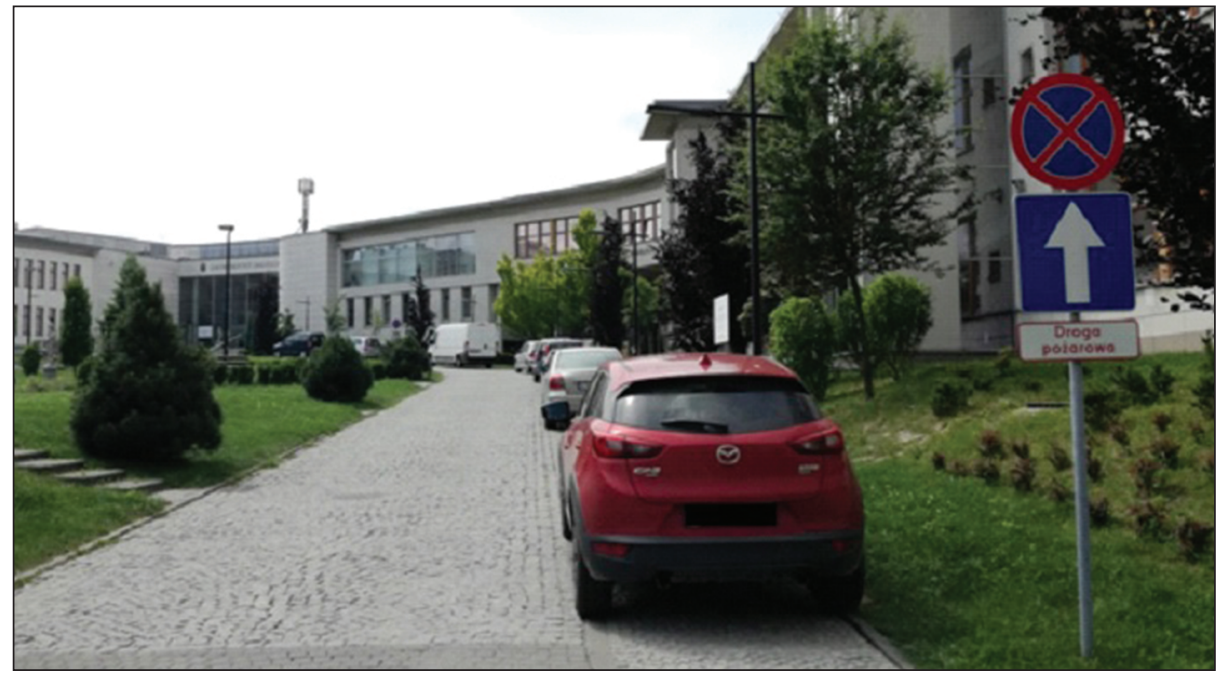

Fot. 1. Samochody pozostawione na drodze pożarowej (fot. J. Biesaga)

Photo 1. Cars parked in a fire road (photo by J. Biesaga)

to koszt ok. 100 zł rocznie, co w ocenie autorów nie było wysoką opłatą. Dochodziło jednak do sytuacji, w której każdy użytkownik mógł wjechać do strefy, ale nie każdy mógł zaparkować swój samochód na parkingu, co prowokowało do pozostawiania pojazdów poza parkingami.

\section{Strefa II - Wydział Fizyki, Astronomii i Informatyki Stosowanej}

Strefa II obejmowała jeden duży parking, na 182 samochody osobowe, z ograniczonym wjazdem dla osób posiadających zezwolenie oraz trzy miejsca przeznaczone dla osób niepełnosprawnych, znajdujące się bliżej wejścia budynku (ryc. 1). Zagospodarowanie przestrzeni skutecznie uniemożliwiało postój poza miejscami wyznaczonymi, nie licząc placu przed głównym wejściem, gdzie realizowane były dostawy do punktów usługowych działających w budynku.

\section{Strefa III - Wydział Chemii}

Parkingi znajdujące się w obrębie Wydziału Chemii można było podzielić na dwie części: parkingi przylegające do budynków, będące swobodnie dostępne dla wszystkich użytkowników oraz parking dwupoziomowy, ograniczony poprzez system kontroli wjazdu. Najmniejszą pojemnością cechował się parking III.2 przewidziany 
na 13 samochodów, a największą drugi poziom parkingu piętrowego (III.6) przewidziany na 69 samochodów. Średnio jedna podstrefa mogła pomieścić 43 pojazdy. Zainteresowanie autorów wzbudził fakt, że strefa III.6, czyli górna płyta parkingu, nie była w ogóle użytkowana podczas trwania badania (zał. 1). Ponadto, pomimo niemal jednakowej atrakcyjności miejsc postojowych i dużej pojemności podstref odnotowano przypadki parkowania poza miejscami wyznaczonymi, co skutkowało zastawianiem ciągów pieszych lub innych pojazdów.

\section{Strefa IV - Wydział Matematyki i Informatyki}

Cechą charakterystyczną Strefy IV było to, że obejmowała obszar jednego z najmniejszych wydziałów na kampusie, a zarazem posiadacza względnie pokaźnego zaplecza parkingowego, włącznie z jedynym na obszarze badań parkingiem podziemnym. Najmniejsza z czterech podstref mieściła 9 samochodów osobowych (IV.1), a największa 94 (IV.3). Średnia pojemność wynosiła 53 pojazdy. Parkingi znajdujące się wokół budynku udostępnione były wszystkim odwiedzającym kampus, za wyłączeniem parkingu podziemnego, który został w całości przeznaczony na potrzeby wydziału. Obie części cieszyły się dużą popularnością wśród użytkowników (ryc. 3).

Nie był to jednak obszar wolny od złych przykładów i praktyk. Podstrefa IV.1 znajdująca się najbliżej wejścia do budynku była nagminnie przepełniona, co wiązało się z postojem samochodów na chodniku i skutecznym utrudnieniem dla pieszych. Jednocześnie w tym samym czasie bez problemu można było znaleźć miejsce na parkingach położonych nieco dalej od wejścia.

\section{Strefa V - Wydział Zarządzania i Komunikacji Społecznej}

Sytuacja na parkingach należących do strefy V była, w ocenie autorów, zadowalająca. Wydział dysponował dwoma parkingami o dużej pojemności, które według zgromadzonych danych były w stanie z nadwyżką odpowiedzieć na zapotrzebowanie użytkowników. Tak jak w pozostałych strefach, największą popularnością cieszył się parking zlokalizowany najbliżej wejścia do budynku. Zagospodarowanie przestrzeni skutecznie uniemożliwiało postój poza miejscami wyznaczonymi, nie licząc pojedynczych przypadków zastawionego chodnika, przecinającego parking V.1. Nagminnym procederem było natomiast pozostawianie samochodów przed głównym wejściem do budynku od strony ul. Łojasiewicza (fot. 2).

Niejednokrotnie znajdowały się tam nie tylko pojazdy związane z realizacją dostaw do punktów usługowych, ale również inne samochody osobowe. W ocenie autorów nie sposób było znaleźć uzasadnienie dla takiej praktyki, bowiem jak wykazano, wydział posiadał niezbędne zaplecze parkingowe dla dużej liczby użytkowników. 


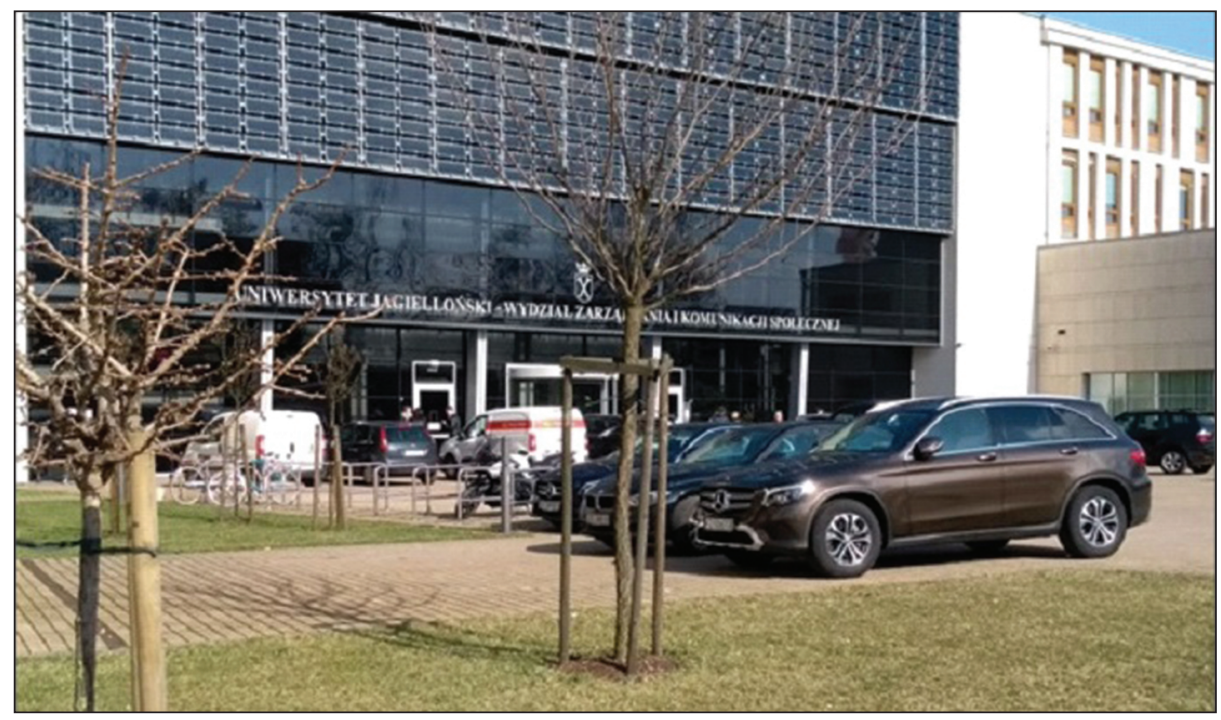

Fot. 2. Samochody zaparkowane przed głównym wejściem Wydziału Zarządzania i Komunikacji Społecznej UJ (fot. G. Bubak)

Photo 2. Cars parked in front of the main entrance of the Faculty of Management and Social Communication (photo by G. Bubak)

\section{Strefa VI - ulice przecinające kampus oraz parking szutrowy}

Pomimo sporej pojemności parkingowej pasów drogowych w ciągu ul. Gronostajowej i ul. Demetrykiewicza nie były to zbyt popularne miejsca do pozostawiania samochodów (tab. 1). Zdarzały się jednak przypadki parkowania na ul. Łojasiewicza, gdzie zatrzymywanie się było zabronione oznakowaniem pionowym. Sporą popularnością cieszył się za to parking szutrowy (VI.1). Z wywiadów przeprowadzonych w terenie wynika, że korzystali z niego nie tylko użytkownicy kampusu, ale także pracownicy okolicznych biurowców oraz mieszkańcy podkrakowskich gmin, którzy przyznali, że był to nieoficjalny parking „Park and Ride”, pozwalający na pozostawienie swojego samochodu i kontynuację podróży komunikacją zbiorową. Niestety skala tego zjawiska nie jest autorom znana.

Zastrzeżenia autorów badania budzi organizacja parkingu szutrowego. Był to nieregularny fragment łąki pokryty tłuczniem. Pojemność parkingu została oszacowana przez autorów na 137 samochodów, jednak pojemność faktyczna zależała od wyobrażeń użytkowników na temat granic parkingu i śmiałości we wjeżdżaniu samochodami w głąb łąki. Dużym problemem organizacyjnym był również brak wyznaczonych 
miejsc do parkowania na tak dużej powierzchni. Zdarzały się sytuacje, gdy kierowcy zastawiali się wzajemnie i powodowali paraliż w ruchu (fot. 3). W ocenie autorów parking ten powinien był zostać zlikwidowany, ponieważ jego funkcjonowanie budziło wątpliwości pod względem estetycznym oraz wpływu na środowisko (Zielińska 2015).

Tab. 1. Parkowanie samochodów na ulicach przecinających kampus

Tab. 1. Parking cars on the streets crossing the campus

\begin{tabular}{|l|c|c|c|c|}
\hline \multirow{2}{*}{$\begin{array}{c}\text { Nazwa ulicy } \\
\text { Street name }\end{array}$} & \multirow{2}{*}{$\begin{array}{c}\text { Miejsca parkingowe } \\
\text { Parking spaces }\end{array}$} & \multicolumn{3}{|c|}{$\begin{array}{c}\text { Średnia liczba samochodów w godzinach: } \\
\text { Average number of cars in hours: }\end{array}$} \\
\cline { 3 - 5 } & & 09.00 & 13.00 & 17.00 \\
\hline Gronostajowa $^{a}$ & 69 & 19 & 27 & 11 \\
\hline Demetrykiewicza $^{b}$ & 43 & 14 & 26 & 10 \\
\hline tojasiewicza $^{c}$ & 0 & 2 & 5 & 3 \\
\hline
\end{tabular}

Objaśnienia: a) brak ograniczeń - postój na zasadach ogólnych, b) zakaz zatrzymywania się po jednej stronie ulicy, c) zakaz zatrzymywania się na całej długości ulicy.

Explanations: a) no restrictions - parking allowed on general terms, b) stopping forbidden on one side, c) stopping forbidden on both sides.

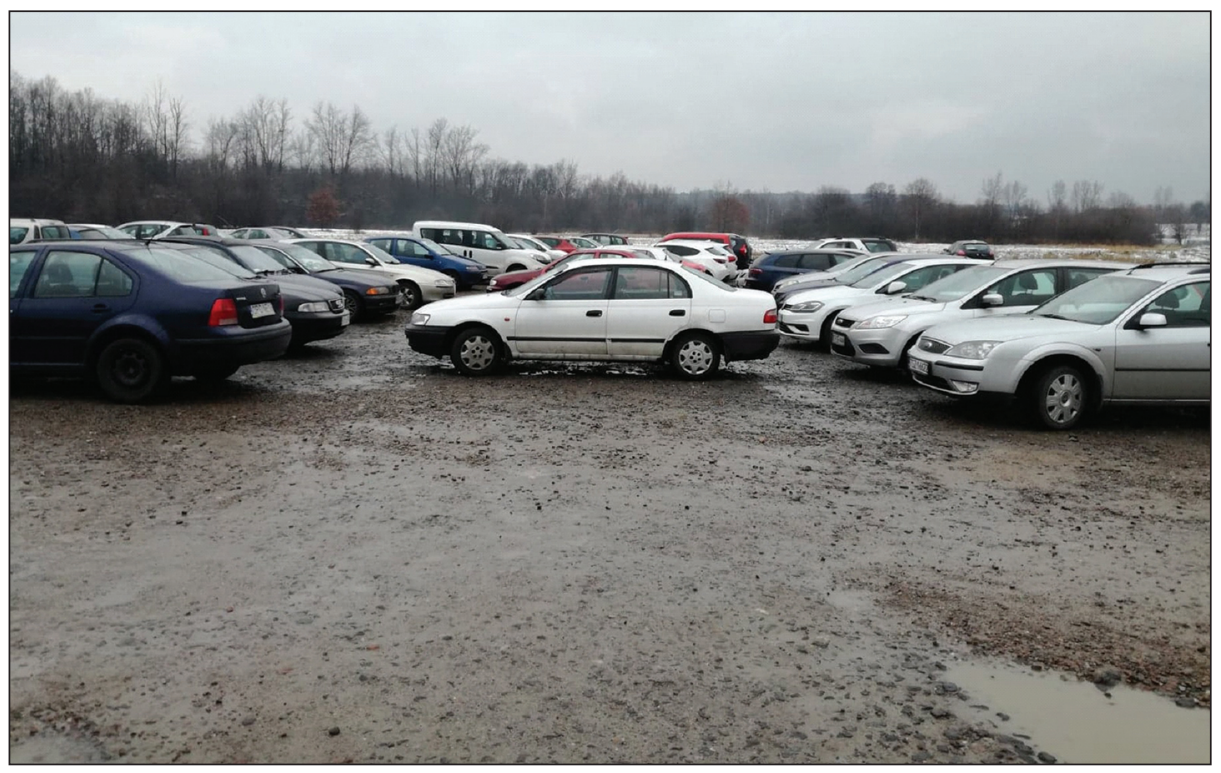

Fot. 3. Zastawione samochody na parkingu szutrowym (fot. J. Biesaga)

Photo 3. Blocked cars on the gravel parking lot (photo by J. Biesaga) 


\section{Dyskusja}

Uzyskane wyniki pozwoliły określić pewne prawidłowości dotyczące użytkowania parkingów na badanym obszarze, których świadomość może być istotna dla użytkowników kampusu. Na podstawie przeprowadzonych pomiarów udało się stwierdzić, że występuje nadwyżka miejsc postojowych względem faktycznego zapotrzebowania. Największe odnotowane zapełnienie oscylowało w okolicach $70 \%$ pojemności całkowitej. Nie zmienia to jednak faktu występowania przepełnienia niektórych podstref, co najczęściej wynikało z nierespektowania obowiązującej organizacji ruchu. Przyczyny tego zjawiska należy doszukiwać się w zróżnicowanej atrakcyjności pomiędzy podstrefami opartej na zlokalizowaniu względem wejść do budynków uczelni. Takie praktyki sprawiają wrażenie jakoby kształtowanie się przestrzeni parkingowej oraz jej funkcjonowanie determinowane było przez oddolne zachowania, aniżeli przemyślaną politykę parkingową. System parkingów został zaprojektowany z ograniczoną liczbą miejsc parkingowych, lecz ich maksymalna liczba była wystawiana na próbę przez zachowania kierowców, które niekiedy dalekie były od założeń organizacyjnych czy przepisów prawa o ruchu drogowym. Zarówno parkowanie przyuliczne (głównie przy ul. Łojasiewicza), jak i samochody pozostawione w miejscach niedozwolonych wpływają negatywnie na poziom bezpieczeństwa. Mogą świadczyć również o niewystarczająco ukształtowanej kulturze jazdy części użytkowników kampusu i jej poprawa powinna być jednym z priorytetów działań administracji w tym zakresie. Świadomość władz uczelni o powyższych prawidłowościach może w przyszłości przysłużyć się do zmodyfikowania infrastruktury parkingów na badanym obszarze oraz przekształceniu polityki parkingowej bliższej idei zrównoważonej mobilności.

Należy jednak zauważyć, że zarządzanie mobilnością to nie tylko polityka parkingowa. Przystąpienie do prac nad planem mobilności wymaga dalszych badań i analiz, szczególnie w celu poznania dokładnego podziału zadań przewozowych w społeczności kampusu, jak również motywacji kierujących użytkownikami w wybieraniu sposobów przemieszczania się. Niniejsze badanie nie uwzględnia bowiem wykorzystania innych środków transportu niż samochody. Co więcej, słabością niniejszego opracowania może być brak informacji o kierowcach konkretnych pojazdów - skąd przyjechali i dokąd udali się po zaparkowaniu samochodu. Wiedza ta z pewnością umożliwiłaby dokładniejsze poznanie i analizę zjawiska.

\section{Wnioski}

Kampus 600-lecia Odnowienia Uniwersytetu Jagiellońskiego w Krakowie posiada zróżnicowane i pojemne zaplecze parkingowe. Istniejące miejsca postojowe z nadwyżką zaspokajają codzienne potrzeby użytkowników. Duży problem stwarza jednak 
nieracjonalne wykorzystanie posiadanych zasobów. Niejednokrotnie dochodzi do sytuacji, gdy kierowcy parkują na chodnikach, trawnikach lub drogach pożarowych, przy jednocześnie niezapełnionych okolicznych parkingach. Kierowcy wykazują silną chęć pozostawienia pojazdu możliwie najbliżej wejścia do budynku, co odzwierciedla się również w rozkładzie przestrzennym popularności miejsc parkingowych. Jak wykazały badania, system kontroli wjazdu nie ma wpływu na jakość zachowań użytkowników.

Postuluje się wprowadzenie zmian organizacyjnych i przestrzennych w celu nadania pieszym priorytetu na obszarze całego kampusu oraz wdrożenie działań edukacyjnych i informacyjnych, mających za zadanie poinformowanie użytkowników o istnieniu problemu oraz zmianę ich przyzwyczajeń transportowych. Konieczne wydaje się również zlikwidowanie niektórych parkingów i wprowadzenie w ich miejsce nowych funkcji, jak również zwiększenie popularności korzystania z istniejącej infrastruktury stałej (m.in. parkingu dwupoziomowego) na rzecz zaniechania korzystania z parkingu szutrowego.

W ocenie autorów istotne jest podejście systemowe do polityki parkingowej i porozumienia się władz wydziałów znajdujących się na terenie kampusu. Jak wykazano, na terenie badań występują obszary, gdzie dostęp do parkingów jest silnie reglamentowany i nieosiągalny dla osób spoza danej jednostki organizacyjnej uczelni. Dobrą praktyką mogłoby być również wprowadzenie jednolitego systemu monitorującego zajętość miejsc parkingowych na całym kampusie, który informowałby kierowców o bieżącym zapełnieniu i rekomendował korzystanie z parkingów, które nie są jeszcze w pełni zajęte (Stawowy, Szmigiel 2014). Konieczne wydają się również wypracowanie i realizacja planu mobilności jako rozwiązania znanego na innych uczelniach (Nosal 2009).

\section{Literatura}

Bagnowska A., Kaczor T., 2009, Ocena oddziatywania inwestycji na system transportowy, Zeszyty Naukowo-Techniczne SITK RP, 138, 9-18.

Feltynowski M., 2016, Wykorzystanie danych præestrzennych dotyczqcych miejsc parkingowych dla celów planowania przestrzennego - przyktad centrum Łodzi, Folia Oeconomica 4(323), 67-80.

Jedynak Z., 2015, Ocena dostępności systemu parkingowego Politechniki Rzeszowskiej, Modern Managment Review, vol. XX, 22 (3), 59-68.

Kowalski M., Górecka A., 2014, Problemy wykorzystania parkingów $P+R$ w Warszawie, Logistyka, 4, 3598-3606.

Majdecka J., Zwoliński T., Niewitała D., 2012, Przeglad rozwiqzań dotyczqcych polityki parkingowej w miastach europejskich, Transport Miejski i Regionalny, 3, 2-22.

Nosal K., 2009, Wptyw planów mobilnosci na smiane sachowań komunikacyjnych, Zeszyty

Naukowo-Techniczne SITK RP, 138, 177-196. 
Rodrigue J-P., Comtois C., Slack B., 2006, The Geography of Transport Systems, Routledge, New York.

Rudnicki A., 2010, Zrównoważona mobilność a rozwój przestrzenny miasta, Czasopismo Techniczne, 1-A, z. 3, 57-74.

Shoup D., 2005, Parking on a smart campus, [w:] D. Mitchell (ed.) California Policy Options, Los Angeles: UCLA School of Public Affairs.

Starowicz W., 2011, Zaræadæanie mobilnościq wyæwaniem polskich miast, Transport Miejski i Regionalny, 1, SITK RP, 42-47.

Stawowy M., Szmigiel A., 2014, Metody detekcji i estymacji sajętości parkingów, Logistyka, 3, 5976-5982.

Templin T., Miecznikowski T., Popielarczyk D., 2014, Wykorzystanie mobilnego GIS do inwentaryzacji miejsc parkingowych na obszarze kampusu uniwersyteckiego w Olsztynie, Logistyka, 3, 6304-6314.

Zielińska E., 2015, Wymagania technicะno-prawne i ekologiczne miejsc parkingowych ze szczególnym uwzględnieniem parkingów wielopoziomowych, Logistyka, 4, 7022-7030.

Grwegor: Bubak (ORCID: 0000-0003-2274-2649)

Uniwersytet Warswawski

Wydziat Geografii i Studiów Regionalnych

ul. Krakowskie Przedmieście 30, 00-927 Warszawa

email: gbubak97@gmail.com

Andræej Jabtoński, Jakub Biesaga

Uniwersytet Jagielloński

Wydziat Geografii i Geologii

Instytut Geografii i Gospodarki Przestrzennej

ul. Gronostajowa 7, 30-387 Kraków 


\begin{tabular}{|c|c|c|c|c|c|c|c|c|c|c|c|c|c|c|c|c|c|c|c|}
\hline \multirow{3}{*}{ 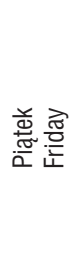 } & $\underset{\Gamma}{8}$ & 0 & m & $\simeq$ & $\infty$ & - & - & 0 & - & $\sim$ & $\infty$ & 으 & $m$ & $\sim$ & $\sim$ & - & $\sim$ & ల్ & 0 \\
\hline & $\begin{array}{l}\text { ठ․ } \\
\dot{m}\end{array}$ & $\AA$ & مـ & 우 & $\underset{\nabla}{ }$ & - & م & $\sim$ & $\stackrel{\nabla}{ }$ & $\stackrel{\llcorner\Omega}{\leftarrow}$ & Lo & $\tau$ & の & $\sim$ & $\infty$ & $\sim$ & 尺ి & $\varnothing$ & 0 \\
\hline & $\varepsilon$ & $\bar{N}$ & مص & 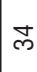 & 0 & - & 0 & - & 으 & o & m & $\approx$ & $\sigma$ & $\sim$ & 0 & - & $\infty$ & $\mathcal{f}$ & 0 \\
\hline & & $\simeq$ & m & $\bar{\sim}$ & N & - & 0 & $m$ & $\tau$ & - & $m$ & a) & $\nabla$ & - & - & - & $\mp$ & $\mathscr{f}$ & | \\
\hline
\end{tabular}

惫 空

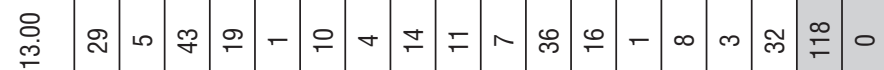

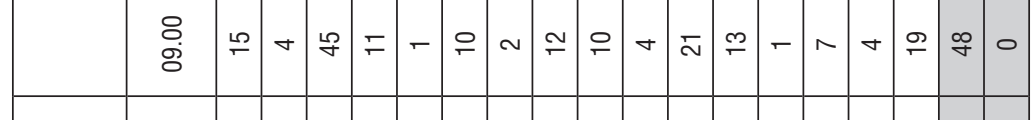

\begin{tabular}{|c|c|c|c|c|c|c|c|c|c|c|c|c|c|c|c|c|c|c|}
\hline 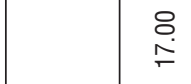 & 음 & 2 & $-\stackrel{2}{L}$ & 2 음 & $2-$ & $\tau$ & - & m & $\sim$ & $m$ & $\stackrel{\infty}{\leftarrow}$ & $\nabla$ & $\tau$ & - & - & $\mp$ & $\stackrel{\infty}{\infty}$ & 0 \\
\hline
\end{tabular}

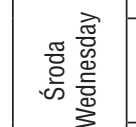

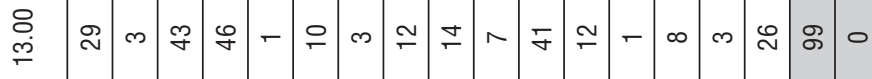

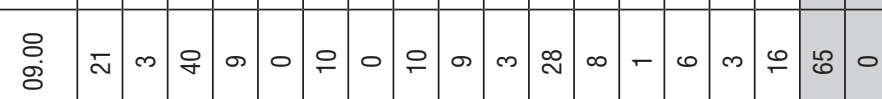

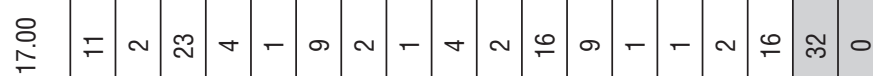

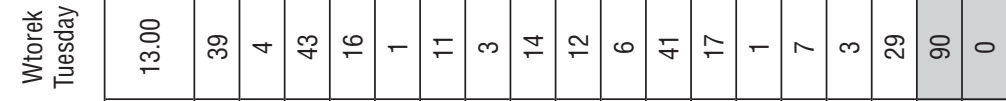

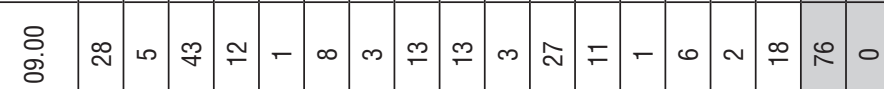

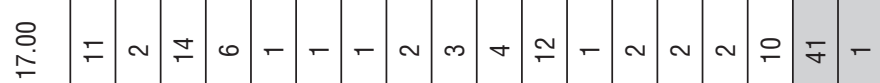

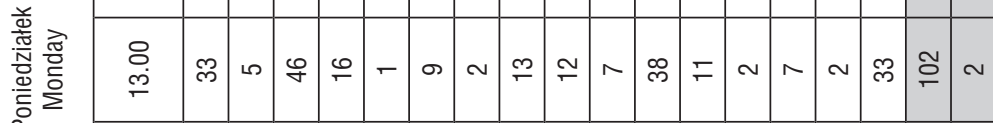

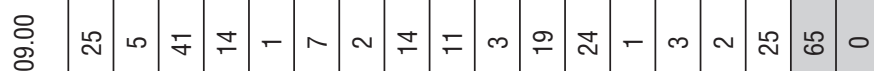

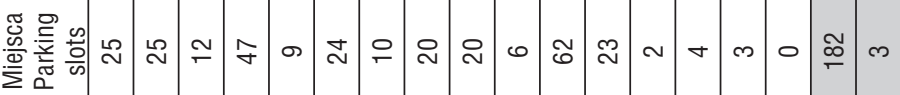

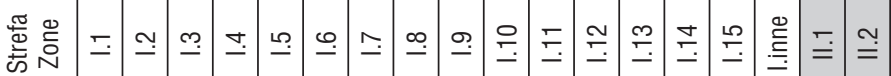




\begin{tabular}{|c|c|c|c|c|c|c|c|c|c|c|c|c|c|c|c|c|c|c|c|c|c|c|}
\hline \multirow{3}{*}{ 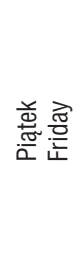 } & $\begin{array}{l}8 \\
\end{array}$ & 0 & $\sim$ & | 10 & 으 & 으 & $\stackrel{\circ 2}{\sim}$ & 0 & 0 & $\mp$ & $\nabla$ & ని & $\approx$ & 0 & $\infty$ & $\stackrel{?}{q}$ & m & $\neq$ & 0 & 0 & 0 & 0 \\
\hline & $\begin{array}{l}\text { ¿ } \\
\text { p. }\end{array}$ & ๓ & ما & 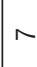 & $\stackrel{d}{d}$ & 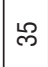 & 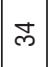 & 0 & 0 & $\stackrel{\nabla}{\nabla}$ & $\stackrel{2}{\sim}$ & in & $\mathscr{\vartheta}$ & 0 & $\stackrel{L}{\sim}$ & in & $\nabla$ & $\stackrel{\mathbb{O}}{\circ}$ & ল & $\stackrel{\infty}{\sim}$ & 10 & 0 \\
\hline & $\begin{array}{l}8 \\
\text { ه }\end{array}$ & - & m & m & $\approx$ & $\stackrel{\sim}{\sim}$ & 尺ి & 0 & $\sim$ & $\stackrel{\circ}{\circ}$ & $\approx$ & $\stackrel{\infty}{\sim}$ & $\mp$ & 0 & $\mp$ & G & m & 8 & $\bar{\sim}$ & $\stackrel{10}{\longrightarrow}$ & $\sim$ & 0 \\
\hline \multirow{3}{*}{ 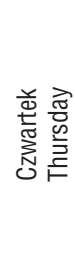 } & 옫 & 0 & 0 & - & $\nabla$ & 0 & $\mp$ & 0 & 0 & $\simeq$ & $\infty$ & ש & m & 0 & স্ & $\overline{10}$ & $\sim$ & in & $\nabla$ & $\mp$ & 0 & 0 \\
\hline & $\begin{array}{l}\text { ه. } \\
\text { m. }\end{array}$ & $\sim$ & $\nabla$ & 1 & $\mathbb{N}$ & లి & $\mathscr{q}$ & 0 & - & 무 & $\mathscr{N}$ & ஜ & 8 & 0 & $\stackrel{\infty}{\infty}$ & $\overline{6}$ & $\sim$ & m) & $\stackrel{2}{\sim}$ & $\stackrel{\sim}{\sim}$ & 0 & - \\
\hline & $\begin{array}{l}\text { வ } \\
\text { g. }\end{array}$ & 0 & - & $\sim$ & $\mathbb{N}$ & $\bar{N}$ & $\stackrel{2}{\sim}$ & 0 & 0 & $\stackrel{\circ}{\Gamma}$ & $\neq$ & L্ল & $\stackrel{\infty}{q}$ & 0 & $\approx$ & 闲 & $\nabla$ & గొర & $\mp$ & $\underset{\sim}{ }$ & ळ & 0 \\
\hline \multirow{3}{*}{ 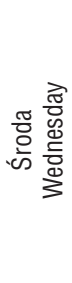 } & $\begin{array}{l}8 \\
\end{array}$ & 0 & $\sim$ & $m$ & $\simeq$ & $\stackrel{0}{\circ}$ & $\stackrel{20}{\sim}$ & 0 & 0 & o & $\nabla$ & $\grave{\sim}$ & $\mathbb{N}$ & 0 & 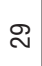 & 守 & $\infty$ & : & $\bar{\sim}$ & $\stackrel{\varphi}{\leftarrow}$ & $m$ & 0 \\
\hline & $\begin{array}{l}\text { ৪ } \\
\stackrel{\oplus}{\longrightarrow}\end{array}$ & 0 & مص & $r$ & $\approx$ & L & 守 & 0 & 0 & $\stackrel{\infty}{=}$ & $\hat{\sim}$ & $\mathscr{L}$ & $\mathscr{\varnothing}$ & 0 & ৪ & $\Xi$ & $\simeq$ & $\hat{m}$ & $\hat{\sim}$ & ్. & $\wedge$ & 0 \\
\hline & ㅇ. & 0 & $\sim$ & $\sim$ & ని & $\cong$ & 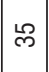 & 0 & 0 & 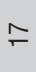 & 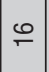 & $\tau$ & g & 0 & g & $\begin{array}{l}\mathbf{0} \\
\end{array}$ & 10 & $\stackrel{\infty}{\curvearrowright}$ & ని & $\simeq$ & $\sim$ & - \\
\hline \multirow{3}{*}{ 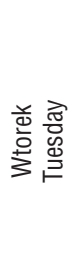 } & $\underset{ }{\stackrel{8}{N}}$ & 0 & $\sim$ & $\sim$ & $\underset{\nabla}{\nabla}$ & $\stackrel{m}{2}$ & $\sigma$ & 0 & 0 & $\simeq$ & $\stackrel{\infty}{-1}$ & $\mathscr{\forall}$ & $\bar{\approx}$ & 0 & $\mp$ & 守 & $\sim$ & ৪ & $\sim$ & $\stackrel{10}{\longrightarrow}$ & $\wedge$ & $\sim$ \\
\hline & 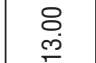 & 0 & $m$ & ما & $\mathscr{N}$ & $\stackrel{\infty}{\infty}$ & $\stackrel{\infty}{\infty}$ & 0 & 0 & $\stackrel{9}{=}$ & m & $\stackrel{2}{\sim}$ & in & 0 & 18 & 8 & ما & б & $\stackrel{\llcorner}{\sim}$ & 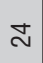 & $\nabla$ & $\sim$ \\
\hline & ৪্. & 0 & $\sim$ & - & $\bar{N}$ & $\stackrel{\infty}{\sim}$ & $\stackrel{N}{2}$ & 0 & - & 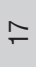 & 으 & 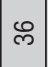 & $\mathscr{F}$ & 0 & 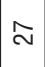 & 8 & 10 & $\approx$ & 마 & ? & 0 & - \\
\hline \multirow{5}{*}{ 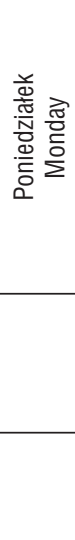 } & 옫 & 0 & $\sim$ & $m$ & $\cong$ & $\stackrel{m}{\div}$ & $F$ & 0 & 0 & $\simeq$ & 으 & m & ๗ & m & $\stackrel{\infty}{\sim}$ & $\ddot{\infty}$ & $\sim$ & $\bar{\sigma}$ & o & $\nabla$ & - & 0 \\
\hline & $\begin{array}{l}\stackrel{8}{0} \\
\text { ’. }\end{array}$ & - & 0 & $\infty$ & $\bar{N}$ & ङ & ₹ & 0 & - & $\stackrel{\nabla}{ }$ & శ్ & ஜ & $\widetilde{ఠ}$ & | & $\widetilde{\sigma}$ & in & - & $\stackrel{\mathbb{T}}{\sim}$ & $\stackrel{2}{\sim}$ & $\approx$ & $\nabla$ & $\tau$ \\
\hline & 웅 & 0 & $\nabla$ & ما & N & $\stackrel{\infty}{\sim}$ & 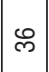 & 0 & 0 & $\stackrel{\circ}{\circ}$ & 으 & ల్ల & $\mathscr{q}$ & $\nabla$ & స్ల & L & $\nabla$ & $\infty$ & $\approx$ & 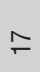 & in & 0 \\
\hline & 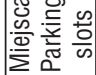 & 0 & $\approx$ & $\stackrel{m}{\longrightarrow}$ & $\approx$ & ○े & 通 & 8 & 0 & $\sigma$ & $\bar{\tau}$ & ठా & 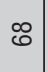 & 0 & $\stackrel{\infty}{\infty}$ & 8 & 0 & 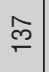 & 8 & $\mathscr{P}$ & 0 & 0 \\
\hline & 萼 & $\stackrel{\varrho}{\stackrel{\Xi}{=}}$ & 立 & 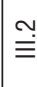 & $\stackrel{\text { }}{\equiv}$ & 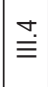 & $\stackrel{\text { L }}{\equiv}$ & $\stackrel{\bullet}{\equiv}$ & $\stackrel{\stackrel{\stackrel{\Xi}{!}}{\equiv}}{\equiv}$ & 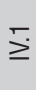 & 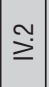 & 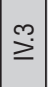 & $\stackrel{+}{\geq}$ & 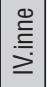 & $\subsetneq$ & $\stackrel{\Upsilon}{\lessgtr}$ & 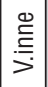 & $\dot{\bar{s}}$ & $\stackrel{\sim}{\rightleftharpoons}$ & $\stackrel{m}{>}$ & $\stackrel{+}{>}$ & 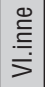 \\
\hline
\end{tabular}

